\title{
Leaf Age-Dependent Effects of Boron Toxicity in Two Cucumis melo Varieties
}

\author{
Theocharis Chatzistathis $^{1}\left(\mathbb{D}\right.$, Dimitrios Fanourakis ${ }^{2}\left(\mathbb{D}\right.$, Sasan Aliniaeifard ${ }^{3}(\mathbb{D})$, Anastasios Kotsiras ${ }^{4}$, Costas Delis ${ }^{4}$ \\ and Georgios Tsaniklidis $5, * \mathbb{D}$
}

1 Institute of Soil and Water Resources, Hellenic Agricultural Organization "ELGO-DIMITRA", 57001 Thessaloniki, Greece; chchatzista@gmail.com

2 Laboratory of Quality and Safety of Agricultural Products, Landscape and Environment, Department of Agriculture, School of Agricultural Sciences, Hellenic Mediterranean University, Estavromenos, 71004 Heraklion, Greece; dimitrios.fanourakis82@gmail.com

3 Photosynthesis Laboratory, Aburaihan Campus, Department of Horticulture, University of Tehran, Tehran 14174, Iran; aliniaeifard@ut.ac.ir

4 Department of Agricultural Technology, School of Agricultural Technology and Food Technology and Nutrition, University of Peloponnese, Antikalamos, 24100 Kalamata, Greece; a.kotsiras@go.uop.gr (A.K.); deliscostas@yahoo.gr (C.D.)

5 Institute of Olive Tree, Subtropical Crops and Viticulture, Department of Viticulture, Vegetable Crops, Floriculture and Plant Protection, Hellenic Agricultural Organization "ELGO-DIMITRA", 32A Kastorias Street, 71307 Heraklion, Greece

* Correspondence: tsaniklidis@elgo.iosv.gr

Citation: Chatzistathis, T.;

Fanourakis, D.; Aliniaeifard, S.;

Kotsiras, A.; Delis, C.; Tsaniklidis, G. Leaf Age-Dependent Effects of Boron Toxicity in Two Cucumis melo Varieties. Agronomy 2021, 11, 759. https://doi.org/10.3390/ agronomy11040759

Academic Editor: Carla Gentile

Received: 26 March 2021

Accepted: 12 April 2021

Published: 13 April 2021

Publisher's Note: MDPI stays neutral with regard to jurisdictional claims in published maps and institutional affiliations.

Copyright: (c) 2021 by the authors. Licensee MDPI, Basel, Switzerland. This article is an open access article distributed under the terms and conditions of the Creative Commons Attribution (CC BY) license (https:/ / creativecommons.org/licenses/by/ $4.0 /)$
Abstract: Boron (B) is an essential nutrient for plant growth and development, exhibiting extremely narrow margins between deficiency and toxicity. B toxicity is devastating for productivity and apparent for a continuously increasing part of agricultural land, under the influence of on-going climate change. In this study, the effects of increased $\mathrm{B}$ supply (by using $\mathrm{H}_{3} \mathrm{BO}_{3}$ ) were addressed by examining critical physiological responses of young and mature leaves, which were devoid of toxicity symptoms, in two melon varieties (Armenian cucumbers, cantaloupes). B was primarily translocated through the transpiration stream, and secondarily via the active cell membrane transport system. The $B$ distribution pattern was independent of leaf age, and remained rather unchanged under increased B supply. Armenian cucumbers, exhibiting higher leaf B levels, underwent an enhanced adverse impact on (root and shoot) growth, photosynthetic pigment content, cellular membrane integrity, and also exhibited attenuated antioxidant defense stimulation. Notably, and unlike other abiotic stressors, no evidence of B toxicity-induced systemic reaction was apparent. B toxicity greatly enhanced the transcription of the genes coding for borate influx and efflux channels, an effect that was mostly evident in mature leaves. In conclusion, shoot physiological responses to B toxicity are highly localized. Moreover, the obstruction of the diffusion and the B translocation to the aerial organs under increased B supply is genotype-dependent, governing plant physiological responses.

Keywords: antioxidant defense; B excess; borate transporter; shoot growth; root growth

\section{Introduction}

Among essential nutrients, boron (B) holds a unique place since it has a very specific participation in the development of the plant body, namely in the formation of rhamnogalacturonan II (RG-II) polysaccharide-boron complexes. These complexes are crucial for cell wall formation and function, as well as for proper pollen-tube growth and fruit set [1-4]. Universally, B deficiency is a common challenge for the productivity of several crops. By contrast, B toxicity is mostly relevant in agricultural environments with water scarcity, in proximity to heavy industrial activity, where increased soil B accumulation is common, or when the use of lower quality water (e.g., treated wastewater) is mandatory for irrigation [1,5-8]. Under this background, the use of agricultural land is often limited 
by $\mathrm{B}$ toxicity in arid parts of the world, as well as in areas hosting heavy industrial activity or employing lower quality irrigation water [1,5-7]. In arid areas, B toxicity-induced limitations are expected to be intensified by climate change through increased frequency of drought events [9]. Cucumis melo L. falls within the crops facing the challenge of high soil B levels, since it is highly cultivated in environments characterized by low or unpredictable water availability [4]. A deeper understanding of B toxicity effects on the physiology of horticultural crops with high economic value is essential not only for the potential expansion of agricultural land, but also for plant productivity under specific environments that are nevertheless not uncommon.

Antioxidant capacity has been linked to abiotic stress tolerance, including B toxicity $[10,11]$. Antioxidants (e.g., phenolics, flavonoids) scavenge toxic reactive oxygen species (ROS), alleviating cellular damage [12]. Collectively, it may be expected that genetic differences in the up-regulation of antioxidant machinery are translated to variation in remedying the adverse effects of B toxicity. New investigations are therefore necessary, focusing on both the stimulation of antioxidant defense owing to B excess, and its role in raising tolerance differences at the intraspecific level.

Textbooks suggest a passive movement of B from the soil through the roots to the plant body via the transpiration stream, without the involvement of an organized cellular mechanism. This assumption was recently revisited by revealing the existence of specific borate channels (B-transferring proteins) in cellular membranes of Arabidopsis thaliana (L.) Heynh and other taxa $[2,13]$. These proteins may mediate intake, transport, or efflux. The nodulin 26-like intrinsic protein (NIP) and boric acid/borate transporter (BOR) families contain the major B transporters, including the root transporters NIP5;1 (boric acid channel) and BOR1 (boric acid/borate exporter) [11]. The NIP5;1 aquaporin facilitates root cell $B$ intake from the soil, whereas the BOR1 efflux transporter is mostly responsible for the $B$ loading into the xylem for transport. The regulation of B-transferring proteins is differentially adjusted under B scarcity or over-supply, suggesting distinctive roles of B uptake and transport. For instance, the BOR4 protein contributes to the B efflux directly from the roots and is induced by under B-oversupply [14]. Increased BOR4 accumulation has been associated with tolerance to B excess [14]. NIP6;1 participates in the distribution of $B$ in the aerial organs by facilitating the $B$ permeation across the cellular membranes, and holds a critical role under B scarcity [15]. BOR2 efflux transporter mediates the B movement from the cell interior to the cell wall for the formation of the RG-II polysaccharide complex [16]. Other B-transferring proteins (e.g., BOR6, BOR7, and NIP7;1) hold highly specific roles mostly associated with reproductive organ development [16]. Despite active transport, B movement towards the apical meristem remains generally slow, suggesting that $B$ toxicity symptoms will be first evident in mature leaves and then appear in younger ones when $B$ is oversupplied. This differential distribution of $B$ between young and mature leaves may not be valid in species that biosynthesize high levels of sugar alcohols, since these bind with $B$ and promptly translocate it to the fast-developing organs $[4,17,18]$. To our knowledge, the B distribution pattern in different age leaves has not been studied in C. melo. Additionally, it remains unknown whether or not it contributes to the genetic diversity in both the appearance and severity of B toxicity symptoms.

To better understand the genetic differences in the tolerance to $B$ toxicity, and the role of the $B$ transport mechanism in this process, we examined critical physiological parameters together with the expression of $B$ transporting channels on both young and mature leaves. Thus, the aims of our study were: (a) to evaluate the effects of $B$ toxicity in the antioxidant machinery of young and mature leaves, (b) to investigate the effects of B toxicity on the B-transport system in the molecular level, and (c) to distinguish differences in the physiological response between varieties that can potentially be useful for the development of more tolerant genotypes. C. melo, as a major horticultural crop, was employed as a model species. The current analysis included two varieties (cantaloupes and Armenian cucumbers), exhibiting remarkable differences in the fruit morphology. 


\section{Materials and Methods}

\subsection{Plant Material and Growth Conditions}

Seeds of cantaloupes (C. melo var. Cantalupensis cv. Retato Degli Ortolani) and Armenian cucumbers (C. Melo var. flexuosus cv. Abruzzese Tortarello) (Hortus Sementi srl, Longiano, Italy) were pre-germinated on moist paper in petri dishes. This period was about one week. Germinated seedlings were transferred in $0.5 \mathrm{~L}$ plastic pots containing vermiculite (Vermiterra, Nordia SA, Athens, Greece), and then placed in a climate-controlled growth chamber $(1 \times \mathrm{w} \times \mathrm{h}=2 \times 4 \times 2 \mathrm{~m})$ from the Laboratory of Vegetable Crops of Institute of Olive Tree, Subtropical Crops and Viticulture (IOSV /Heraklion, Crete, Greece). Environmental conditions during plant growth were air temperature of $26.1 \pm 1.5^{\circ} \mathrm{C}$, relative air humidity of $60.2 \pm 1.2 \%$ and a light intensity of $300 \mu \mathrm{mol} \mathrm{m}^{-2} \mathrm{~s}^{-1}$ photosynthetic photon flux density at the plant level for $12 \mathrm{~h}$ per day provided by fluorescence lamps (HQI-BT $400 \mathrm{~W} / \mathrm{D}$ pro, Osram, Berlin, Germany). Control plants received a custom-made nutrient solution ( $6 \%$ nitrate, $5.2 \%$ ammonium, $8.8 \%$ urea, $20 \% \mathrm{P}_{2} \mathrm{O}_{5}, 20 \% \mathrm{~K}_{2} \mathrm{O}, 5 \% \mathrm{CaCl}_{2}$, $0.0251 \% \mathrm{Mg}, 0.02 \% \mathrm{~B}, 0.05 \% \mathrm{Cu}, 0.1 \% \mathrm{Fe}, 0.05 \% \mathrm{Mn}, 0.001 \% \mathrm{Mo}$, and $0.05 \% \mathrm{Zn}$ ) diluted $(0.1 \%, w / v)$ in water $\left(1.26 \mathrm{mS} \mathrm{cm}^{-1}\right)$. Boron-stressed plants received the above-mentioned solution, including $1 \mathrm{mM}$ of boric acid $\left(\mathrm{H}_{3} \mathrm{BO}_{3}\right.$; MERCK, Darmstadt, Germany) [19]. The solution was replenished weekly to sustain the $\mathrm{pH}$ and Electrical Conductivity at constant levels. Plants were fertigated three times a week, and cultivation lasted five weeks. In this way, potting-media moisture was maintained at or near maximum water holding capacity. All evaluations were conducted following $35 \mathrm{~d}$ of growth under the employed B level regimes. At that time, no visible symptoms of B toxicity were apparent. To assess both the onset and severity of B toxicity symptoms, an additional set of plants was left to grow for another $10 \mathrm{~d}$.

Plant and leaf level measurements were conducted. Leaf-level measurements included mature (close to the root-to-shoot intersection) and young (close to the apical meristem) leaves, representing a range in leaf age. In both cases, sampled leaves had grown under direct light, were fully-expanded, and devoid of toxicity symptoms. In all cases, the time between sampling and the start of the evaluation did not exceed $15 \mathrm{~min}$. For metabolite and biochemical assays, leaf samples were placed in vials, flash-frozen in liquid nitrogen and transferred to a freezer $\left(-80^{\circ} \mathrm{C}\right)$ for storage. Replicate leaves were collected from separate plants. All measurements were conducted in ten plants per treatment. To minimize border effects, experimental plants were surrounded by border plants (adjacent to chamber walls) that were not sampled. The main experiment was performed after a pre-experiment where the main effects of B toxicity on C. melo plants were evaluated, and technical aspects of the experiment were fine-tuned.

\subsection{Plant Growth and Morphology}

To evaluate the effect of B toxicity on plant growth and morphology, leaf area, together with leaf, stem, and root dry masses were recorded. The roots were assessed following removal of the substrate via gentle washing. Leaf area (one-sided surface area) was determined with a leaf area meter (Li-3000A; Li-Cor Inc., Lincoln, NE, USA), and dry weight (DW) was assessed ( \pm 0.01 g; MXX-412; Denver Instruments, Bohemia, NY, USA) after drying the tissue at $75^{\circ} \mathrm{C}$ for $48 \mathrm{~h}$ (UM200 oven, Memmert GmbH, Schwabach, Germany). Root-to-shoot ratio (root mass/shoot mass), specific leaf area (SLA; leaf area/leaf mass), and leaf mass ratio (LMR; leaf mass/plant mass) were calculated.

Five and ten days following destructive measurements (i.e., 40 and $45 \mathrm{~d}$ of growth, respectively), leaf images were obtained in another set of plants by using a digital camera (Canon EOS M2; Canon Inc., Tokyo, Japan). The camera-to-leaf distance was maintained constant.

\subsection{Foliar Macro- and Micro-Nutrient Content}

Leaf mineral analysis was performed. Leaves were washed with distilled water and then dried as described above. Afterward, they were grounded into fine powder, assessed 
by using a 30-mesh screen. A $0.5 \mathrm{~g}$ fine powder portion was dry-ashed in a muffle furnace $\left(515{ }^{\circ} \mathrm{C}\right.$ for $5 \mathrm{~h}$ ). Then, the ash was dissolved in $3 \mathrm{~mL}$ of $6 \mathrm{~N} \mathrm{HCl}$ and diluted with double distilled water up to $50 \mathrm{~mL}$. The concentrations of $\mathrm{P}, \mathrm{K}, \mathrm{Ca}, \mathrm{Mg}, \mathrm{Fe}, \mathrm{Mn}, \mathrm{Zn}$ and $\mathrm{Cu}$ were determined by ICP (Optical Emission Spectrometer, OPTIMA 2100 DV, Perkin Elmer, Waltham, Massachusetts, US) [20], while N was determined by the Kjeldahl method [21].

\subsection{Photosynthetic Pigment Content}

The B toxicity on leaf photosynthetic pigment (chlorophyll, carotenoids) content was assessed. Leaf samples were processed immediately after collection. Following fine chopping, portions weighing $75 \mathrm{mg}$ were homogenized with the addition of $10 \mathrm{~mL}$ of $80 \%$ acetone. This primary acetone extract was then transferred in falcon tubes, kept in the dark for $1 \mathrm{~h}$, and vortexed at $15 \mathrm{~min}$ intervals. A centrifugation $(4400 \times g$ for $5 \mathrm{~min})$ at $4{ }^{\circ} \mathrm{C}$ was then performed. Since chlorophyll is light sensitive, extraction took place in a dark room [22]. The obtained extract was subjected to reading on a spectrophotometer (Mapada UV-1800; Shanghai. Mapada Instruments Co., Ltd., Shanghai, China). Chlorophyll a, chlorophyll b, total chlorophyll (i.e., Chlorophyll a + chlorophyll b), and carotenoid contents were calculated by employing the following equations [23]:

$$
\begin{gathered}
{\left[\mathrm{Chl}_{\mathrm{a}}\right]=12.25 \mathrm{~A}_{663}-2.79 \mathrm{~A}_{647}} \\
{\left[\mathrm{Chl}_{\mathrm{b}}\right]=21.5 \mathrm{~A}_{647}-5.1 \mathrm{~A}_{663}} \\
{[\mathrm{Car}]=\left\{1000 \mathrm{~A}_{470}-1.82\left[\mathrm{Chl}_{\mathrm{a}}\right]-85.02\left[\mathrm{Chl}_{\mathrm{b}}\right]\right\} / 198}
\end{gathered}
$$

\subsection{Total Phenolic and Total Flavonoid Contents}

The accumulation of non-enzymatic antioxidants (phenolics, flavonoids) was assessed as an indication of the antioxidant machinery activity [12]. The extraction of phenolics and flavonoids was performed by homogenizing frozen leaves with $80 \%$ acetone $(v / v)$ in deionized water ( $3 \mathrm{~mL} \mathrm{~g}^{-1}$ tissue) with mortar and pestle. The mixture was placed in a super-sonic ice bath $\left(4^{\circ} \mathrm{C}\right.$ under darkness) for $15 \mathrm{~min}$, and then centrifuged $(4000 \times g$ for $5 \mathrm{~min})$. The procedure was repeated three times [24].

Leaf total phenolic (TP) content was estimated using the Folin-Ciocalteu colorimetric method [25] with minor modifications as described in Kafkaletou et al. [24]. Briefly, $0.2 \mathrm{~mL}$ of the diluted extract with distilled water (1:2) was added into a tube containing $0.2 \mathrm{~mL}$ Folin-Ciocalteu reagent and $2.6 \mathrm{~mL}$ deionized water. After stirring, the tube was stored at room temperature $\left(25^{\circ} \mathrm{C}\right)$ for $6 \mathrm{~min}$. Then, $2 \mathrm{~mL} \mathrm{Na} \mathrm{CO}_{3}(7 \%, w / v)$ were added to the mixture and the absorbance was measured at $750 \mathrm{~nm}$ using a spectrophotometer (Mapada UV-1800; Shanghai. Mapada Instruments Co., Ltd., Shanghai, China) versus a blank, after $90 \mathrm{~min}$ incubation at room temperature $\left(25^{\circ} \mathrm{C}\right)$. For TP content, gallic acid was used as the standard reference, and gallic acid equivalent (GAE) was expressed as mg per $\mathrm{kg}$ fresh mass.

Leaf total flavonoid (TF) content was assayed using the aluminum chloride colorimetric method. Quercetin was used as a standard to make the calibration curve according to [26]. One $\mathrm{mL}$ of leaf extract was mixed with $0.2 \mathrm{~mL}$ of $10 \%(w / v) \mathrm{AlCl}_{3}$ solution in acetone, $0.2 \mathrm{~mL}$ potassium acetate $(1 \mathrm{M})$ and $5.6 \mathrm{~mL}$ water. The mixture was incubated for $30 \mathrm{~min}$ at room temperature $\left(25^{\circ} \mathrm{C}\right)$, followed with the measurement of absorbance at $415 \mathrm{~nm}$ against a blank. For TF content, rutin was used as the standard reference, and rutin equivalent (RUE) was expressed as $\mu \mathrm{g}$ per $\mathrm{g}$ fresh mass.

\subsection{Thiobarbituric Acid Reactive Substances' Content}

As an indication of lipid peroxidation, the content of thiobarbituric acid reactive substances (TBARS) was evaluated. Leaf fresh tissue $(0.5 \mathrm{~g})$ was homogenized in $10 \mathrm{~mL}$ of $0.1 \%$ trichloroacetic acid (TCA) at $4{ }^{\circ} \mathrm{C}$. After centrifugation $\left(4400 \times g\right.$ at $\left.4{ }^{\circ} \mathrm{C}\right)$ for $10 \mathrm{~min}$, the supernatant was used for the assay. The content of TBARS was determined after the reaction with $0.5 \%$ of 2 -thiobarbituric acid in $20 \%$ TCA $(w / v)$, as calculated from 
the subtraction of the absorbance at 532 and $600 \mathrm{~nm}$ using the extinction coefficient of $155 \mathrm{mmol}^{-1} \mathrm{~cm}^{-1}[27,28]$.

\section{7. qPCR Experiments}

Total RNA was extracted from leaf tissue using the method described in Tsaniklidis et al. [29]. Briefly, $1 \mathrm{~g}$ tissue was grounded in $10 \mathrm{~mL}$ of "lysis buffer" $(8 \mathrm{M} \mathrm{GuHCl}$, $25 \mathrm{mM}$ EDTA, 1\% Sarcosyl, 2\% Triton X-100, $25 \mathrm{mM}$ sodium citrate, $0.2 \mathrm{M}$ sodium acetate; $\mathrm{pH}$ adjusted to 5.2 with acetic acid). The lysate was incubated at $65^{\circ} \mathrm{C}$ for $10 \mathrm{~min}$ and then centrifuged $(16,000 \times g$ for $10 \mathrm{~min})$. Half $\mathrm{ml}$ of the supernatant was transferred to a fresh tube and $625 \mu \mathrm{L}$ of absolute ethanol was added (to obtain $55.5 \%$ final concentration). Subsequently, the mixture flowed through a silica column (FT-2.0 Filter-Tube Spin-ColumnSystem, G. Kisker GbR, Steinfurt, Germany) by centrifugation $(1500 \times g$ for $10 \mathrm{~min})$. The column was washed once with $700 \mu \mathrm{L}$ of "wash buffer 1" $(4 \mathrm{M} \mathrm{GuHCl}, 25$ $\mathrm{mM}$ Tris- $\mathrm{HCl} \mathrm{pH} 6.6$, and $60 \%$ ethanol) and twice (700 and $400 \mu \mathrm{L}$, respectively) with "wash buffer 2" ( $2 \mathrm{mM}$ Tris- $\mathrm{HCl} \mathrm{pH} \mathrm{7.0,20} \mathrm{mM} \mathrm{NaCl}$, and $80 \%$ ethanol) by centrifugation $(8000 \times g$ for $1 \mathrm{~min})$. RNA was finally recovered in $50 \mu \mathrm{L}$ of preheated $\left(80^{\circ} \mathrm{C}\right)$ nuclease-free elution buffer (10 mM Tris-HCl, pH 8.0). Total RNA was treated with DNAase I (ThermoFisher, Waltham, MA, USA) and inactivated via heating $\left(74^{\circ} \mathrm{C}\right)$. CDNA synthesis was performed with the Superscript II cDNA synthesis kit (ThermoFisher, Waltham, MA, USA) according to the manufacturer's instructions.

C. melo nucleotide sequences were retrieved from the public database of the National Center for Biotechnology Information (NCBI); RCA1 (XM_008465876), BOR efflux transporters (BOR1: XM_008449232.2; BOR2: XM_008440256.2; BOR4: XM_008449257.2) and NIP aquaporins (NIP5;1: XM_008439275.2; NIP6;1: XM_008455944.2) (Supplementary Table S1). Primers for the above-mentioned nucleotide sequences were designed using the Beakon designer software suite. Quantitative PCR amplifications were performed using the PowerUp ${ }^{\text {TM }}$ SYBR $^{\circledR}$ Green Master Mix (ThermoFisher, Waltham, MA, USA) and a QuantStudio 3 Real-Time PCR System (ThermoFisher, Waltham, MA, USA). The relative quantification of gene expression was performed as previously described, and cantaloupe cytochrome oxidase (EU069547) was used for normalization and calculations. The obtained patterns were verified by using Ubiquitin primers (XM_008456320) [29,30].

\subsection{Hydrogen Peroxide Assay}

Hydrogen peroxide $\left(\mathrm{H}_{2} \mathrm{O}_{2}\right)$ accumulation was spectrophotometrically determined as described by Tsaniklidis et al. [29]. Hydrogen peroxide content was expressed per fresh weight basis.

\subsection{Statistical Analysis}

The experimental study design consisted of three separate biological replicates (across all measurements). Each biological replicate (ten bulked plants) was analyzed three times (qPCR was repeated twice). The statistical significance across treatments was inferred employing a parametric one-way analysis of variance (ANOVA) for each C. melo variety individually. Subsequently, the estimated least significant differences (LSD) of treatment effects were determined $(p=0.05)$. Data were presented as the mean \pm standard deviation (SD) of three replicates. For the statistical analysis, the software package Statgraphics Centurion (Statgraphics Technologies, Inc, The Plains, VA, USA) was used.

\section{Results}

3.1. Temporal and Spatial Incidence of B toxicity Symptoms, and B toxicity Effect on Plant Growth and Morphology

Plants were evaluated at $35 \mathrm{~d}$ of growth under different $\mathrm{B}$ level regimes. At that time, no visible symptoms were apparent in plants grown under B toxicity level (Figure 1A). Following $40 \mathrm{~d}$ of growth (i.e., $5 \mathrm{~d}$ following sampling), B toxicity symptoms were limited to mature leaves (close to the root-to-shoot intersection) of both C. melo varieties under 
study. These included chlorotic areas, which were located at the leaf lamina tip and margins (Figure 1B). Following $45 \mathrm{~d}$ of growth (i.e., $10 \mathrm{~d}$ following sampling), the chlorotic areas progressively became necrotic and expanded to cover most of the lamina area (Figure 1C). These symptoms first appeared in Armenian cucumbers and later on in cantaloupes. No visible symptoms were detected in the young leaves (close to the apical meristem), stems or roots.
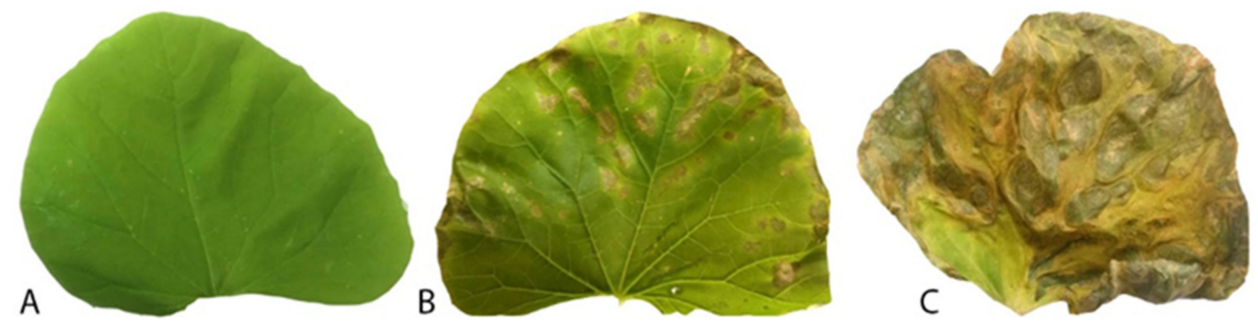

Figure 1. Temporal sequence of Boron (B) toxicity leaf symptomatology. Mature leaves (close to the root-to-shoot intersection) of Armenian cucumbers (C. melo var. flexuosus cv. Abruzzese Tortarello) were imaged under oversupply of $\mathrm{B}$ (by using $\mathrm{H}_{3} \mathrm{BO}_{3}$ ). (A) No visible symptoms ( $1 \mathrm{mM}$ B-treated plants sampled at $35 \mathrm{~d}$ ); (B) Less severe symptoms (1 mM B-treated plants sampled at $40 \mathrm{~d}$ ); (C) Severe symptoms (1 mM B-treated plants sampled at $45 \mathrm{~d})$.

B toxicity caused an adverse effect on the growth of both C. melo varieties (Table 1). $B$ toxicity caused an adverse effect on both leaf area development and plant biomass accumulation (Table 1). In both C. melo varieties, the B toxicity-induced decrease of plant DW was mediated by reduced leaf and root DW, since stem DW was not affected (Table 1).

Table 1. Effect of the oversupply of $\mathrm{B}$ (by using $\mathrm{H}_{3} \mathrm{BO}_{3}$ ) on growth and morphology of cantaloupes (C. melo var. Cantalupensis cv. Retato Degli Ortolani) and Armenian cucumbers (C. melo var. flexuosus cv. Abruzzese Tortarello). Growth period lasted $35 \mathrm{~d}$, where no visible B toxicity symptoms were apparent (Figure 1). Means followed by different letters indicate significant differences ( $p=0.05$; per cultivar comparison in columns). Values are the mean of ten replications ( \pm SD). DW, dry weight; SLA, specific leaf area; LMR, leaf mass ratio.

\begin{tabular}{|c|c|c|c|c|c|c|c|c|}
\hline & Leaf DW (g) & Shoot DW (g) & Root DW (g) & Total DW (g) & $\begin{array}{l}\text { Leaf Area }\left(\mathrm{cm}^{2}\right. \\
\left.\text { Plant }^{-1}\right)\end{array}$ & SLA $\left(\mathrm{cm}^{2} \mathrm{~g}^{-1}\right)$ & LMR $\left(\mathrm{g} \mathrm{g}^{-1}\right)$ & $\begin{array}{l}\text { Root-to-Shoot } \\
\text { Ratio }\left(\mathrm{g} \mathrm{g}^{-1}\right)\end{array}$ \\
\hline $\begin{array}{c}\text { Cantaloupes } \\
\text { Control }\end{array}$ & $0.397 \pm 0.040^{\mathrm{a}}$ & $0.142 \pm 0.030^{b}$ & $0.146 \pm 0.015^{\mathrm{a}}$ & $0.685 \pm 0.052^{\mathrm{a}}$ & $228.9 \pm 18.8^{a}$ & $576 \pm 70^{\mathrm{b}}$ & $0.579 \pm 0.065^{\mathrm{a}}$ & $1.02 \pm 0.25^{\mathrm{a}}$ \\
\hline $\begin{array}{l}\text { Cantaloupes } \\
+ \text { B }\end{array}$ & $0.338 \pm 0.025^{b}$ & $0.140 \pm 0.031^{b}$ & $0.124 \pm 0.023 \mathrm{ab}$ & $0.602 \pm 0.045^{\mathrm{a}}$ & $185.0 \pm 18.4^{\mathrm{bc}}$ & $547 \pm 66^{\mathrm{b}}$ & $0.561 \pm 0.059^{a}$ & $0.89 \pm 0.27^{\mathrm{a}}$ \\
\hline $\begin{array}{l}\text { Armenian } \\
\text { cucumbers } \\
\text { Control }\end{array}$ & $0.289 \pm 0.020^{c}$ & $0.254 \pm 0.044^{\mathrm{a}}$ & $0.137 \pm 0.014^{\mathrm{a}}$ & $0.680 \pm 0.047^{a}$ & $202.5 \pm 12.5^{a b}$ & $700 \pm 37^{b}$ & $0.425 \pm 0.050^{b}$ & $0.54 \pm 0.09^{b}$ \\
\hline $\begin{array}{c}\text { Armenian } \\
\text { cucumbers + B }\end{array}$ & $0.219 \pm 0.022^{d}$ & $0.268 \pm 0.036^{a}$ & $0.114 \pm 0.017^{b}$ & $0.600 \pm 0.041^{a}$ & $156.7 \pm 17.0^{c}$ & $717 \pm 78^{b}$ & $0.363 \pm 0.045^{b}$ & $0.43 \pm 0.05^{b}$ \\
\hline
\end{tabular}

Plant morphology was assessed by evaluating leaf thickness (approximated by SLA), mass partitioning to the leaves (LMR), and root-to-shoot ratio. In both C. melo varieties, leaf thickness was not affected by B toxicity (Table 1). Biomass partitioning to the leaves was reduced by $B$ toxicity in Armenian cucumbers, whereas root-to-shoot ratio was decreased in both C. melo varieties (Table 1).

\subsection{Effect of B toxicity on Photosynthetic Pigment Content and on RCA1 Gene Expression}

The effect of B toxicity on leaf photosynthetic pigment (chlorophyll, carotenoids) content was assessed on both young and mature leaves (Figure 2). In both C. melo varieties, photosynthetic pigment content was not significantly affected by B toxicity.

B toxicity significantly impacted the RCA1 transcription in mature leaves of both C. melo varieties. By contrast, in young leaves, reduced levels of $R C A 1$ transcription were evident only in Armenian cucumbers (Figure 2). 

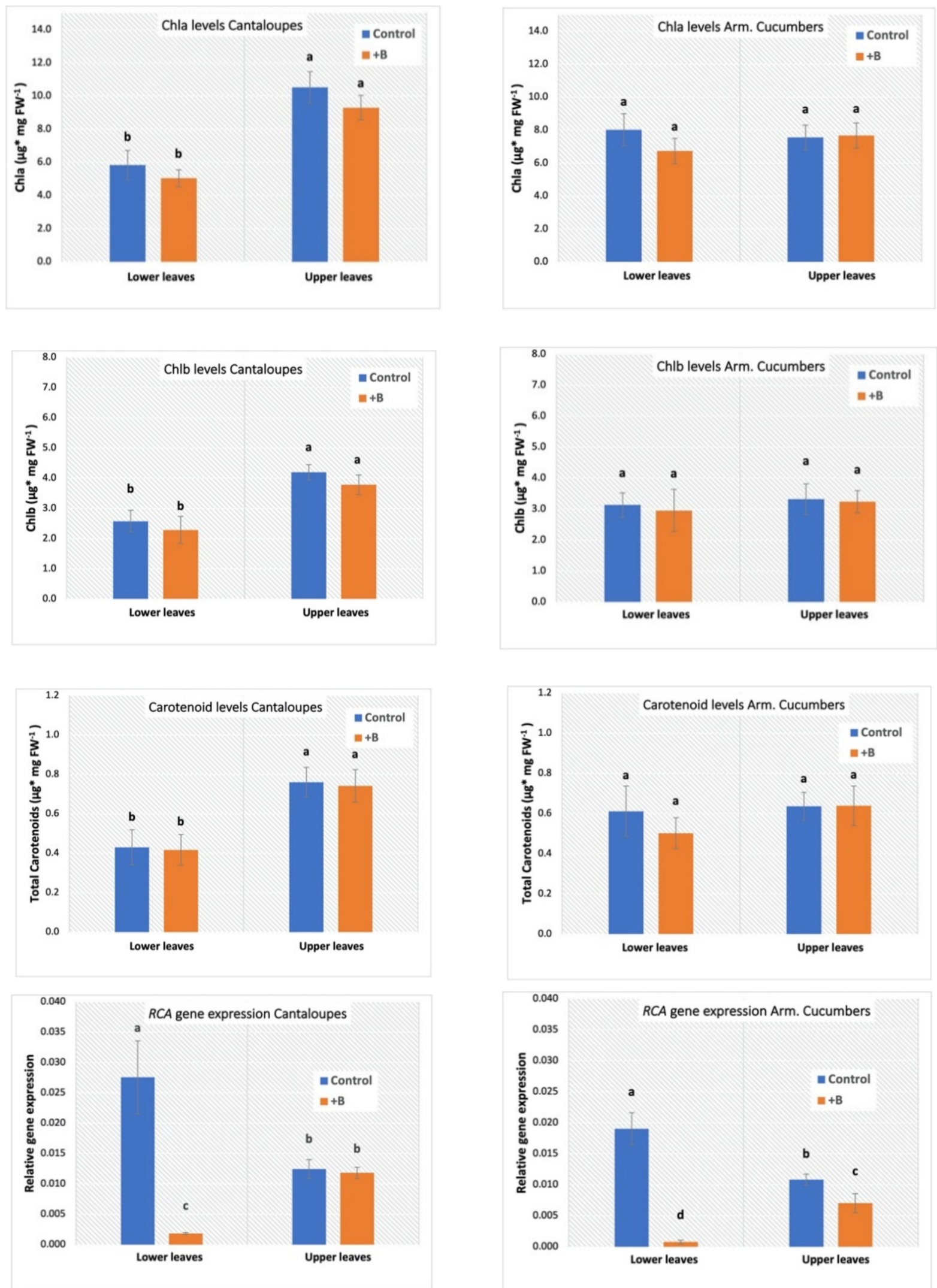

Figure 2. Effect of the oversupply of $\mathrm{B}$ (by using $\mathrm{H}_{3} \mathrm{BO}_{3}$ ) on the photosynthetic pigment (chlorophyll, carotenoids) content and on RCA1 gene expression of young (close to the apical meristem) and mature (close to the root-to-shoot intersection) leaves of cantaloupes (C. melo var. Cantalupensis cv. Retato Degli Ortolani) and Armenian cucumbers (C. melo var. flexuosus cv. Abruzzese Tortarello). Growth period lasted $35 \mathrm{~d}$, where no visible B toxicity symptoms were apparent (Figure 1). Means followed by different letters indicate significant differences $(p=0.05)$. Values are the mean of ten replications $( \pm S D)$. 


\subsection{Effect of B toxicity on Total Phenolic, Total Flavonoid, Thiobarbituric Acid Reactive Substances' and $\mathrm{H}_{2} \mathrm{O}_{2}$ Contents}

In both $\mathrm{C}$. melo varieties, an increased accumulation of non-enzymatic antioxidants (phenolics, flavonoids) was noted in mature leaves, whereas no such effect was apparent in young leaves (Figure 3). In either variety, increased TBARS accumulation was also limited to mature leaves (Figure 3). A similar pattern was revealed for $\mathrm{H}_{2} \mathrm{O}_{2}$ level (Table 2).
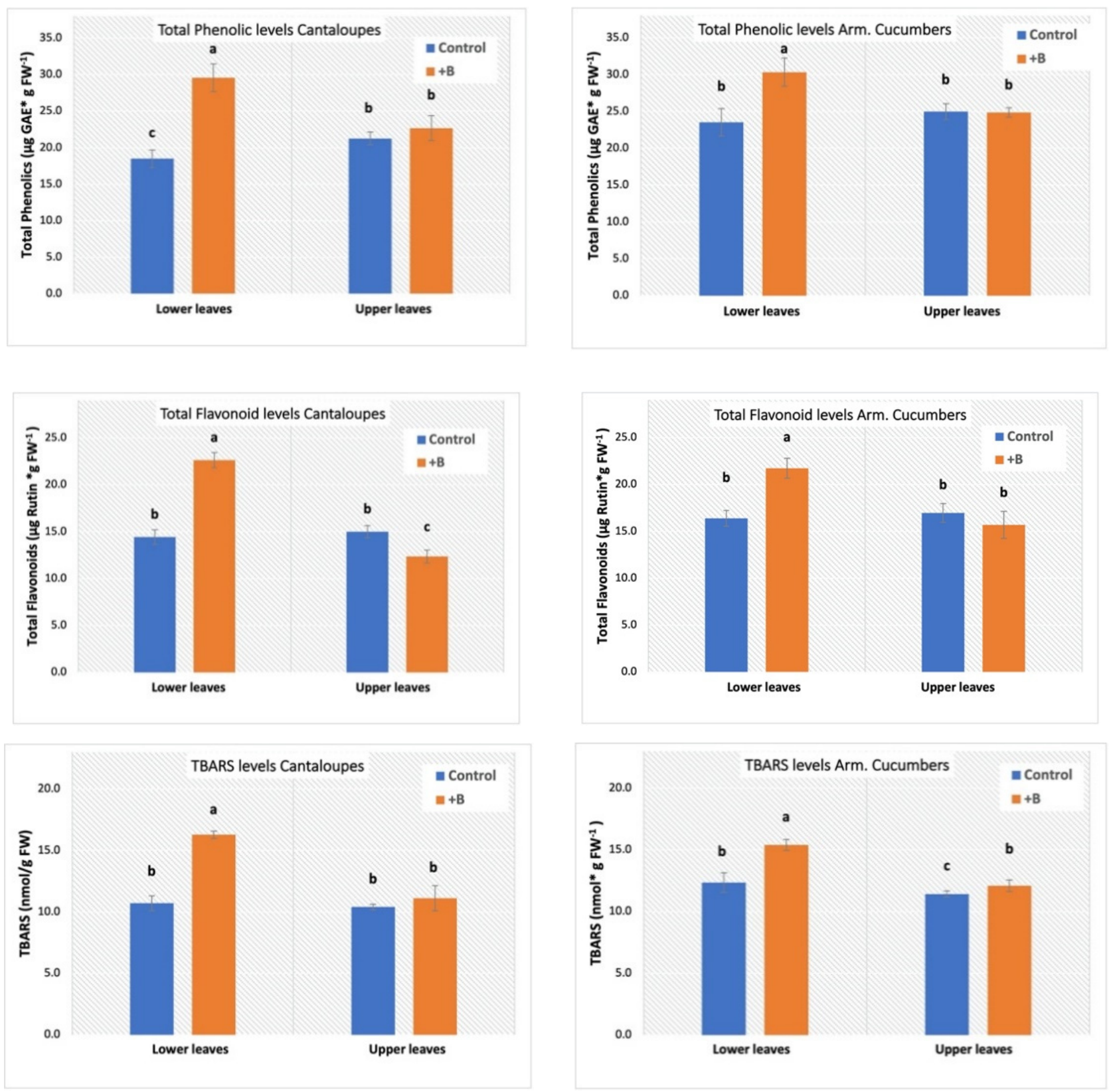

Figure 3. Effect of the oversupply of $\mathrm{B}$ (by using $\mathrm{H}_{3} \mathrm{BO}_{3}$ ) on total phenolic, total flavonoid and thiobarbituric acid reactive substances' (TBARS) contents of young (close to the apical meristem) and mature (close to the root-to-shoot intersection) leaves of cantaloupes (C. melo var. Cantalupensis cv. Retato Degli Ortolani) and Armenian cucumbers (C. Melo var. flexuosus cv. Abruzzese Tortarello). Growth period lasted $35 \mathrm{~d}$, where no visible B toxicity symptoms were apparent (Figure 1). Means followed by different letters indicate significant differences $(p=0.05)$. Values are the mean of ten replications $( \pm \mathrm{SD})$. 
Table 2. Effect of the oversupply of $\mathrm{B}$ (by using $\mathrm{H}_{3} \mathrm{BO}_{3}$ ) on the $\mathrm{H}_{2} \mathrm{O}_{2}$ level of young (close to the apical meristem) and mature (close to the root-to-shoot intersection) leaves of cantaloupes (C. melo var. Cantalupensis cv. Retato Degli Ortolani) and Armenian cucumbers (C. Melo var. flexuosus cv. Abruzzese Tortarello). Growth period lasted $35 \mathrm{~d}$, where no visible B toxicity symptoms were apparent (Figure 1). Means followed by different letters indicate significant differences $(p=0.05)$. Values are the mean of ten replications $( \pm \mathrm{SD})$. Content was expressed per fresh weight basis.

\begin{tabular}{ccc}
\hline & \multicolumn{2}{c}{$\mathbf{H}_{\mathbf{2}} \mathbf{O}_{2}$ Content $\left(\mu \mathbf{m o l ~ g}^{-\mathbf{1}}\right)$} \\
\hline Cantaloupes Lower leaves & Control & $+\mathbf{B}$ \\
\hline Cantaloupes Upper leaves & $0.440 \pm 0.031^{\mathrm{c}}$ & $0.687 \pm 0.039^{\mathrm{a}}$ \\
\hline Armenian cucumbers Lower leaves & $0.560 \pm 0.056^{\mathrm{b}}$ & $0.597 \pm 0.053^{\mathrm{ab}}$ \\
\hline Armenian cucumbers Upper leaves & $0.525 \pm 0.054^{\mathrm{c}}$ & $0.771 \pm 0.051^{\mathrm{a}}$ \\
\hline
\end{tabular}

\subsection{Effect of B toxicity on Foliar Macro- and Micro-Nutrient Content}

In both $C$. melo varieties, $\mathrm{B}$ toxicity generally decreased leaf $\mathrm{N}$ content, whereas it increased $\mathrm{P}, \mathrm{Ca}, \mathrm{Mg}$ and $\mathrm{Mn}$ contents (Table 3). In either variety, B toxicity also drastically increased B content (Figure 4). This increase in B content was much more prominent in mature leaves as compared to the young ones (Figure 4).

Table 3. Effect of the oversupply of $\mathrm{B}$ (by using $\left.\mathrm{H}_{3} \mathrm{BO}_{3}\right)$ on foliar macro- and micro-nutrient content of cantaloupes $(C$. melo var. Cantalupensis cv. Retato Degli Ortolani) and Armenian cucumbers (C. melo var. flexuosus cv. Abruzzese Tortarello). Growth period lasted $35 \mathrm{~d}$, where no visible B toxicity symptoms were apparent (Figure 1). Measurements were conducted on combined young and mature leaves. Means followed by different letters indicate significant differences $(p=0.05$; per cultivar comparison in columns).

\begin{tabular}{|c|c|c|c|c|c|c|c|c|c|c|}
\hline Treatment & N (\%) & $\mathrm{P}(\%)$ & K (\%) & Ca (\%) & $\operatorname{Mg}(\%)$ & $\underset{\left(\mathrm{mg} \cdot \mathrm{kg}^{-1}\right)}{\mathrm{Mn}}$ & $\underset{\left(\mathrm{mg} \cdot \mathrm{kg}^{-1}\right)}{\mathrm{Zn}}$ & $\begin{array}{c}\mathrm{Fe} \\
\left(\mathrm{mg} \cdot \mathrm{kg}^{-1}\right)\end{array}$ & $\begin{array}{c}\mathrm{Cu} \\
\left(\mathrm{mg} \cdot \mathrm{kg}^{-1}\right)\end{array}$ & $\mathrm{Na}(\%$ d.w.) \\
\hline $\begin{array}{l}\text { Cantaloupes } \\
\text { Control }\end{array}$ & $5.61 \pm 0.73^{a}$ & $2.04 \pm 0.17^{b}$ & $3.57 \pm 0.22^{\mathrm{a}}$ & $0.95 \pm 0.10^{b}$ & $1.52 \pm 0.19^{b}$ & $143 \pm 28^{a}$ & $36 \pm 4^{\mathrm{a}}$ & $123 \pm 38^{a}$ & $41 \pm 7^{\mathrm{a}}$ & $0.62 \pm 0.10^{b}$ \\
\hline $\begin{array}{l}\text { Cantaloupes } \\
+\mathrm{B}\end{array}$ & $5.24 \pm 0.57^{\mathrm{a}}$ & $2.47 \pm 0.29 \mathrm{ab}$ & $3.59 \pm 0.33^{\mathrm{a}}$ & $1.34 \pm 0.18^{\mathrm{a}}$ & $2.14 \pm 0.32^{\mathrm{a}}$ & $184 \pm 40^{\mathrm{a}}$ & $43 \pm 6^{\mathrm{a}}$ & $133 \pm 41^{\mathrm{a}}$ & $28 \pm 3^{b}$ & $0.88 \pm 0.12^{\mathrm{a}}$ \\
\hline $\begin{array}{l}\text { Armenian } \\
\text { cucumbers } \\
\text { Control }\end{array}$ & $6.84 \pm 0.77^{a}$ & $2.26 \pm 0.28^{a b}$ & $2.26 \pm 0.37^{b}$ & $0.92 \pm 0.11^{b}$ & $1.26 \pm 0.17^{b}$ & $139 \pm 54^{\mathrm{a}}$ & $42 \pm 8^{a}$ & $157 \pm 27^{\mathrm{a}}$ & $33 \pm 5^{\mathrm{a}}$ & $0.42 \pm 0.09^{c}$ \\
\hline $\begin{array}{l}\text { Armenian } \\
\text { cucumbers } \\
+\mathrm{B}\end{array}$ & $5.51 \pm 0.46^{\mathrm{a}}$ & $2.60 \pm 0.31^{a}$ & $2.09 \pm 0.35^{b}$ & $1.21 \pm 0.14^{\mathrm{a}}$ & $1.92 \pm 0.25^{a}$ & $178 \pm 34^{\mathrm{a}}$ & $043 \pm 6^{a}$ & $113 \pm 23^{a}$ & $31 \pm 6^{a}$ & $0.46 \pm 0.08^{c}$ \\
\hline
\end{tabular}
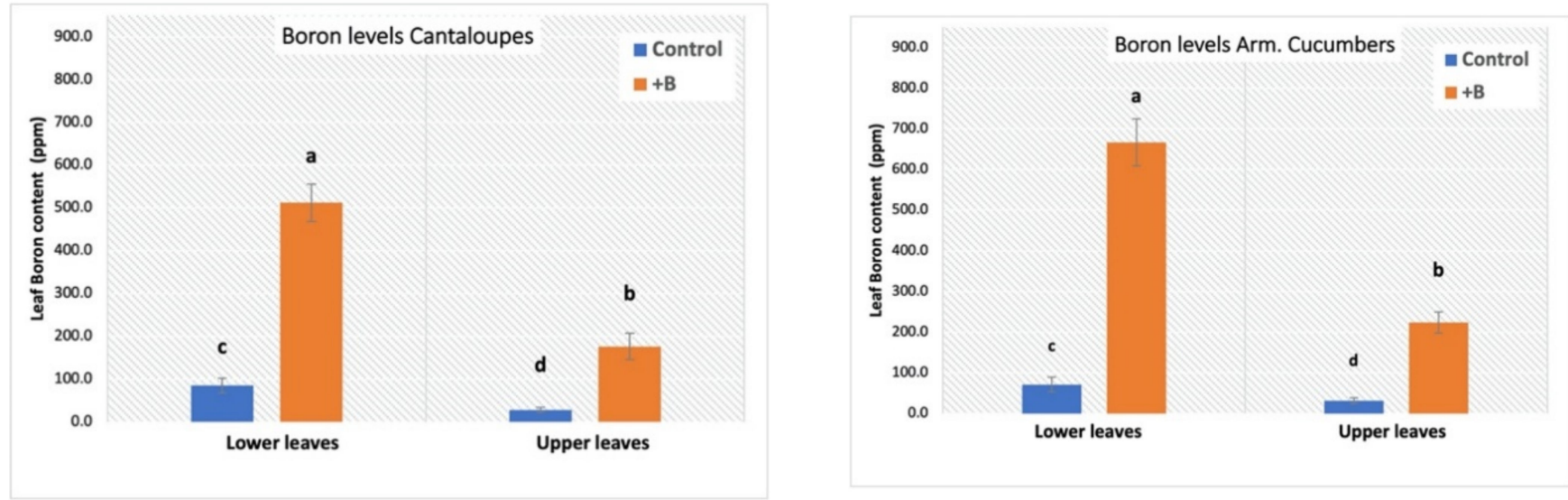

Figure 4. Effects of the oversupply of $\mathrm{B}$ (by using $\mathrm{H}_{3} \mathrm{BO}_{3}$ ) on $\mathrm{B}$ content of young (close to the apical meristem) and mature (close to the root-to-shoot intersection) leaves of cantaloupes (C. melo var. Cantalupensis cv. Retato Degli Ortolani) and Armenian cucumbers (C. melo var. flexuosus cv. Abruzzese Tortarello). Growth period lasted $35 \mathrm{~d}$, where no visible B toxicity symptoms were apparent (Figure 1). Means followed by different letters indicate significant differences $(p=0.05)$. Values are the mean of ten replications $( \pm S D)$. 


\subsection{Effect of B toxicity on Genes Coding for B transporters}

B oversupply had a divergent effect on the transcription of genes coding for NIP aquaporins and BOR transporters (Figures 5 and 6). BOR1 transporter expression exhibited reduced expression in both young and mature leaves of both varieties of B-stressed plants, however, the magnitude of the variation was substantially higher in the mature leaves (Figure 6). BOR2 transporter exhibited reduced expression only in the mature leaves of B-stressed plants. In contrast, B over-supply resulted in increased transcription of the BOR4 transporter but only in mature leaves (Figure 6). Finally, B toxicity remarkably reduced the NIP aquaporin transcription in the mature leaves of both $C$. melo varieties and also in the young leaves of cantaloupes (Figure 5).
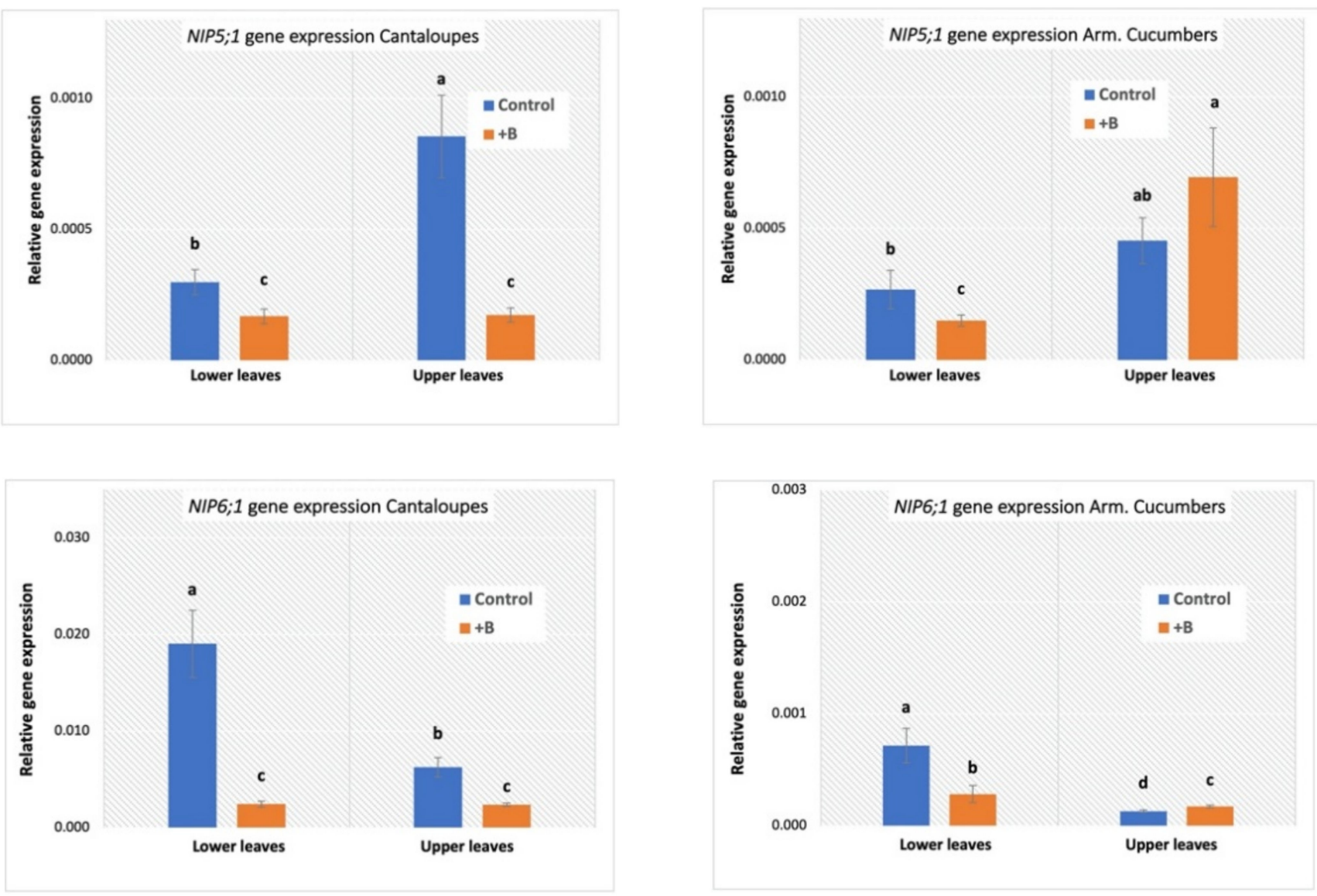

Figure 5. Effect of the oversupply of $\mathrm{B}$ (by using $\mathrm{H}_{3} \mathrm{BO}_{3}$ ) on NOD26-like intrinsic proteins 5;1 and 6;1 (NIP5;1 and NIP6;1 aquaporin, respectively) transcription of young (close to the apical meristem) and mature (close to the root-to-shoot intersection) leaves of cantaloupes (C. melo var. Cantalupensis cv. Retato Degli Ortolani) and Armenian cucumbers (C. melo var. flexuosus cv. Abruzzese Tortarello). COX was used as a reference gene. Growth period lasted $35 \mathrm{~d}$, where no visible B toxicity symptoms were apparent (Figure 1). Means followed by different letters indicate significant differences $(p=0.05)$. Values are the mean of ten replications $( \pm \mathrm{SD})$. 

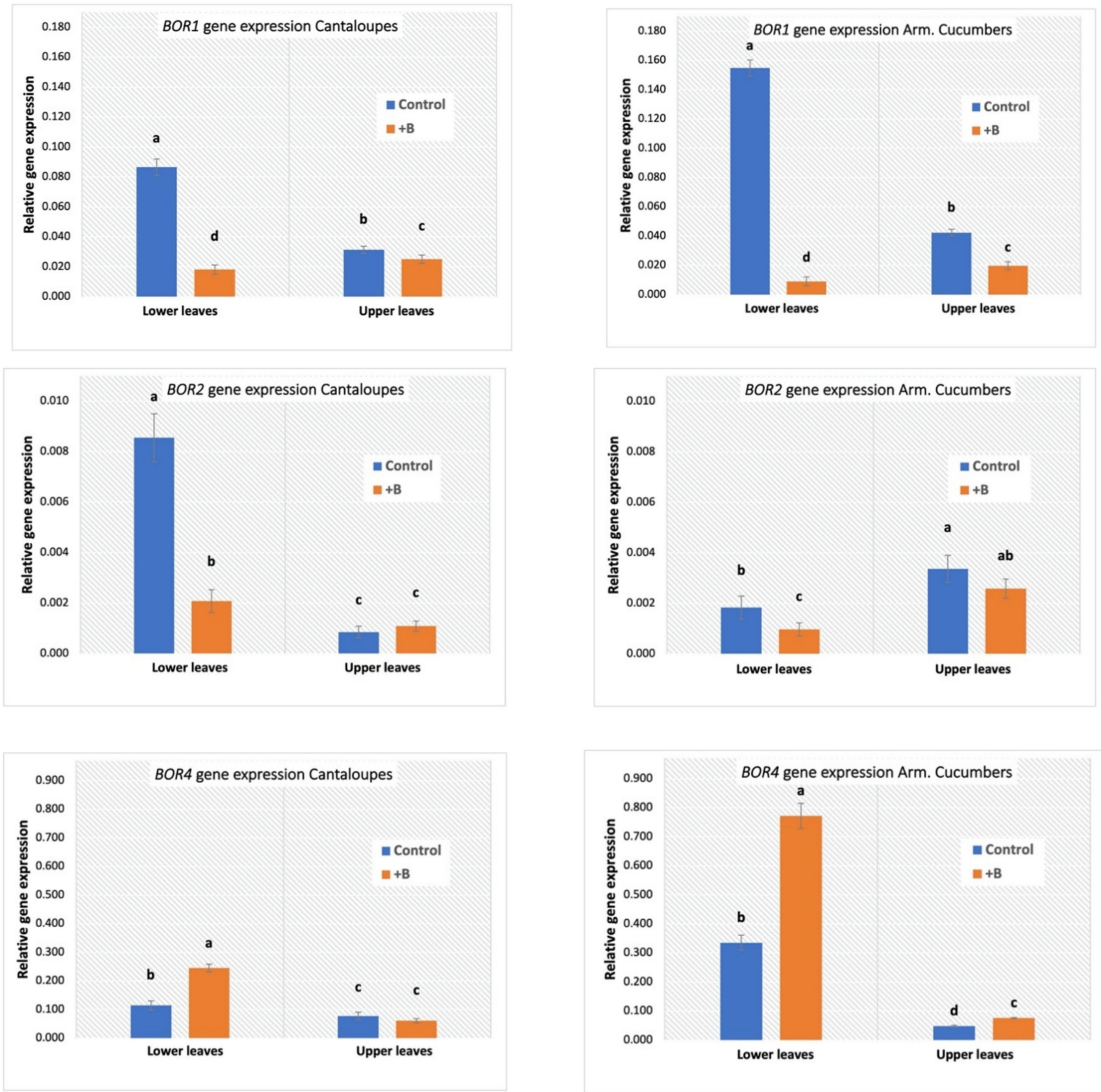

Figure 6. Effect of the oversupply of $\mathrm{B}$ (by using $\left.\mathrm{H}_{3} \mathrm{BO}_{3}\right)$ on Boron efflux transporter (BOR1, BOR2, and BOR4) transcription of young (close to the apical meristem) and mature (close to the root-to-shoot intersection) leaves of cantaloupes ( $C$. melo var. Cantalupensis cv. Retato Degli Ortolani) and Armenian cucumbers (C. nelo var. flexuosus cv. Abruzzese Tortarello). COX was used as a reference gene. Growth period lasted $35 \mathrm{~d}$, where no visible B toxicity symptoms were apparent (Figure 1). Means followed by different letters indicate significant differences $(p=0.05)$. Values are the mean of ten replications $( \pm \mathrm{SD})$.

\section{Discussion}

\subsection{Growth Impairment and Symptomatology of B toxicity}

The severity and advancement of symptomatology suggest that both $C$. melo varieties were highly susceptible to B toxicity, causing extensive damage (Figure 1). All evaluations of the current study were, however, designed to be conducted at a stage ( $35 \mathrm{~d})$ where no visible B toxicity symptoms were apparent (Figure 1).

In control plants of both $C$. melo varieties, mature leaves had elevated leaf $B$ content as compared to young ones (Figure 4). The B oversupply-induced increase in leaf B levels was also much more prominent in mature leaves as compared to young ones (Figure 4). 
This distribution pattern indicates that in C. melo, B is primarily translocated through the transpiration stream, and secondarily via the active cell membrane transport system $[1,4,31]$. This underlines the spatial sequence of B toxicity symptom appearance, with mature leaves being the first ones undergoing such adverse signs (Figure 1; see also [32]). Since B accumulation is strongly influenced by transpiration, both conditions of decreased water use [33] or selection of low transpiring genotypes [34,35] are expected to alleviate the B-induced adverse effects.

The foliar B levels were substantially higher in Armenian cucumbers as compared to cantaloupes (Figure 4), which coincided with increased toxicity symptom severity in the former as compared to the latter. These results might be taken to indicate that the level of $B$ uptake obstruction is strongly genotype-dependent under B toxicity conditions, and this differential B uptake obstruction underlies the concomitant tolerance.

Growth impairment of the aerial organs, another common B toxicity symptom, was also generally more prominent in Armenian cucumbers as compared to cantaloupes (Table 1). Golberg et al. [19] recorded a similar trend under increasing B levels on melons. It is suggested by previous studies on other species that the decreased biomass accumulation under these conditions is mediated through impaired leaf functionality $[4,36]$. Our results indicate that the B-induced reduction in biomass accumulation is mediated by both reduced leaf area development (thus reduced light interception; [37]) and decreased photosynthetic activity (see RCA1 transcription; Figure 2). B is a highly reactive element, and when present in excess inside plant cells can react with molecules critical for both photosynthesis and cellular metabolism [38]. This decrease in photosynthetic activity was not induced by alterations in leaf photosynthetic pigment content (Figure 2). The rubisco activation by RCA is heavily influenced by the leaf redox status acting as a limiting factor. However, under severe oxidative stress, the RCA transcription decreases, resulting in reduced RuBiSCo activation, thus increasing the redox potential inside the chloroplasts $[39,40]$. Moreover, the decline of the photosynthetic rate was recently correlated to the irregular cell wall pectin structure [41], since B is heavily involved in pectin formation. Although a regulatory mechanism appears to be present [42], the irregularity of the cell wall structure owing to B deposition may adversely affect leaf functionality [28].

In both $C$. melo varieties, $\mathrm{B}$ toxicity significantly affected the $R C A 1$ transcription while marginally affecting leaf photosynthetic pigment content. B toxicity, however, has been related to a remarkable leaf proteome alteration [43], the impairment of photosynthesis, indicated here by the significant reduction of $R C A 1$ transcription in both varieties, can be a major factor contributing to the growth retardation caused by B toxicity [43].

\subsection{Expression of Genes Coding for BOR Transporter Gene Family and NIP Aquaporins under B toxicity}

Since B transporters in roots are involved in the B uptake and movement towards the aerial part, their regulation can be a key factor for B toxicity tolerance [44]. However, it was recently discovered that $B$ also moves from the leaves towards the root through the phloem, a process that can also modulate B equilibrium [45]. This modulation of B equilibrium through the leaves is not yet fully investigated, especially under B excess.

NIP aquaporins are mainly water transferring channels, which passively facilitate the intake of several macromolecules, including boric acid. B toxicity reduces the expression of several aquaporins in the roots and consequently reduces the water [46-48]. Since NIP aquaporins are the major boric acid gateways to the cytoplasm, it may be expected that similarly to roots, the transcription of the respective genes is also reduced in the leaves to obstruct the B influx into the cell under B toxicity [48]. Indeed, the transcription of both NIP5;1 and NIP6;1 aquaporin genes was significantly reduced under B toxicity (Figure 5). Interestingly, this decrease in transcription was more prominent in mature leaves as compared to young ones (Figure 5), indicating a strong correlation between the expression of NIP transporters and B levels. The higher level of decrease in NIP aquaporin transcription noted in cantaloupes, as compared to Armenian cucumbers (Figure 5), most probably mediates the enhanced tolerance to B toxicity of cantaloupes. 
In Arabidopsis roots, different physiological roles and transcriptional response to $\mathrm{B}$ toxicity have been reported for each BOR transporter [1]. In this study, BOR1 and BOR2 transporters exhibited reduced transcription in mature leaves of both $C$. melo varieties under B toxicity, whereas the BOR4 transcription was significantly induced (Figure 6). By contrast, the effect of B toxicity on the transcription of BOR transporters in young leaves was minimal and somewhat evident only in Armenian cucumbers (Figure 6). Along with NIP5;1, the role of BOR1 is critical when B is at scarcity. Under these conditions, the transcription of both NIP5;1 and BOR1 genes is induced to increase the B flow inside the plant body via the xylem. By contrast under B toxicity, reduced transcription, protein and mRNA degradation as well as proteolysis reduce the accumulation of BOR1 proteins in a similar fashion to NIP5;1 [44,49,50], indicating that BOR1 is induced only under B scarcity and does not participate in the physiological reactions under B toxicity [51]. In mature $C$. melo leaves, a similar pattern for gene transcription with the one found in the Arabidopsis roots is revealed for BOR1 transporter under B toxicity. A highly delicate mechanism unique for BOR1 and highly dependent on the B level was found, governing its transcriptional regulation individually for each cell $[44,52]$. Given their main function as antiporters, the decrease in transcription of most BOR genes is rather unexpected. However, Yoshinari and Takano [50] suggest that under the negative membrane potential of borate anion $\left[\mathrm{B}(\mathrm{OH})_{4}{ }^{-}\right], \mathrm{BOR}$ channels can function as uniporters facilitating the borate anion uptake. While in the cytoplasm B exists mainly as borate anion, in the apoplast it is readily converted to boric acid, thus generating a negative borate anion gradient and a positive boric acid gradient between the cytoplasm and the apoplast. As both the uptake of boric acid via the NIP transporters and borate via the BOR channels can create toxicity inside the plant cells, the reduced transcription can be explained [50]. Moreover, Takano et al. [53] suggest that the disarrangement of BOR1 transporter in shoots is used as an obstacle for the movement of $\mathrm{B}$ towards the younger vegetation.

In Arabidopsis, another BOR transporter paralog (BOR2), while having high similarity to BOR1, has been found to participate exclusively in the B-RGII linking in the cell walls [54]. In loquat trees, $B$ toxicity increased the cell wall thickness in stems, suggesting an increased rate of B deposition in this cellular structure [27]. In this study, however, B toxicity resulted in reduced expression of BOR2 gene in the mature leaves of both $C$. melo varieties (Figure 6). In accordance with our results, Miwa et al. [55] indicated that the regulation of BOR2 in Arabidopsis was like the one of BOR1 and regardless of its functionality, B toxicity leads to increased BOR2 protein degradation. We suggest that a level of control in the diversion of $B$ towards the cell wall exists that prevents the excessive B deposition in the cell walls via the BOR2 channels. Indeed, Wu et al. [42] revealed that under B stress the increase of B in the cell walls of trifoliate orange is much smaller than B concentration in the cytoplasm.

The transcription of BOR4 efflux transporter, which is associated with the capacity of pumping $B$ to the apoplast, has been related to improved B toxicity tolerance $[14,56]$. In this study, the BOR4 transcription was induced under B toxicity in mature leaves of both C. melo varieties (Figure 6). Since BOR4 is mainly localized on the plasma membrane and exports B from the cytoplasm to the apoplast, it has been suggested to contribute to the increased B toxicity tolerance by altering the B distribution in Arabidopsis leaves [54]. The placement of the excess $B$ in the apoplast renders it less toxic, and in case of rainfall it can be readily leached by the rain, actively reducing its concentration in the leaves [56]. An almost twofold increase of the BOR4 transcription was found in the mature leaves of both C. melo varieties (Figure 6), although the B levels in cantaloupes were lower than those in Armenian cucumbers (Figure 4). A strong effect on the transcription of both BOR1 and $B O R 4$ was evident in the mature leaves of both $C$. melo varieties, whereas in young leaves such an effect was only distinguishable in Armenian cucumbers (Figure 6), correlating with the higher leaf B content in both young and mature leaves of this variety (Figure 4). These results might be taken to indicate that the transcription of $B$ transporters is initiated upon threshold changes in the B equilibrium. 


\subsection{Leaf Antioxidant Machinery Activation and Mineral Status under B toxicity}

$B$ toxicity induced significant effects in the levels of total phenolics and total flavonoids, as well as led to increased contents of TBARS products and $\mathrm{H}_{2} \mathrm{O}_{2}$ in both $C$. melo varieties under study (Figure 3; Table 2), suggesting a level of cellular metabolism deregulation upon $B$ toxicity before the onset of visible symptoms (Figure 1). Kekec et al. [8] reported that B toxicity has caused DNA damage and genomic instability in both Triticum aestivum and Phaseolus vulgaris plants. This phenomenon has been compared to the phytotoxic activity of heavy metal elements [57] that can also cause extensive cellular damage and trigger the ROS production. It has been demonstrated that the antioxidant machinery stimulation can provide a level of protection against $B$ toxicity [10] and such a reaction has been recorded in several species (reviewed in Landi et al. [4]). Cervilla et al. [38] reported that $\mathrm{B}$ toxicity inhibits the $\mathrm{NO}_{3}$ reduction, decreases $\mathrm{N}$ levels, and induces the assimilation of $\mathrm{NH}_{4}{ }^{+}$into amino acids via the glutamine synthetase (GS)/glutamate synthase (GOGAT) and glutamate dehydrogenase (GDH) mechanism. This effect of B toxicity was also evident in our experiment, where although the levels of most macro and micronutrients were marginally affected, total $\mathrm{N}$ was reduced in the mature leaves of both $\mathrm{C}$. melo varieties (Table 3).

The deregulation of the $\mathrm{C} / \mathrm{N}$ balance results in metabolic and hormonal imbalance that along with the damages in DNA structure can also promote ROS generation in the affected organs (reviewed in Landi et al. [4]). Similarly to the effects on gene transcription, the stimulation of the studied parameters of the antioxidant machinery was confined in mature leaves, reinforcing the conclusion that the physiological reaction to the B toxicity is not spontaneous. Unlike other abiotic stresses (e.g., salinity), B toxicity appears to be particular in the sense that a systemic reaction is not readily initiated, a phenomenon deserving further investigation.

\section{Conclusions}

Several physiological responses to $\mathrm{B}$ toxicity (by using $\mathrm{H}_{3} \mathrm{BO}_{3}$ ) were examined in young and mature leaves of two Cucumis melo varieties (Armenian Cucumbers, cantaloupes). Evaluations were conducted at a period where no visible symptoms were apparent. B distribution followed similar patterns in both varieties with higher levels in mature leaves and lower levels in younger ones. This pattern was highly conservative under B toxicity. The increased sensitivity to B toxicity of Armenian cucumbers was manifested by impaired (root and shoot) growth and weakened antioxidant defense stimulation, which resulted in a higher cellular damage level. The transcription of the genes coding for borate influx and efflux channels was greatly enhanced by B toxicity, an effect that was mainly evident in mature leaves. In conclusion, a high level of localization was noted in leaf physiological responses to B toxicity. Interestingly, the noted obstruction of B diffusion and translocation was variety-dependent, and seems to underlie the noted sensitivity to B toxicity.

Supplementary Materials: The following are available online at https:/ /www.mdpi.com/article/10 .3390 /agronomy11040759/s1, Table S1: Primers used for the qPCR experiments.

Author Contributions: T.C. performed the mineral analysis; D.F., S.A., A.K. and C.D. assisted the data interpretation, edited the manuscript and provided valuable insights; G.T. conceived and supervised the study. All authors have read and agreed to the published version of the manuscript.

Funding: This research received no external funding.

Institutional Review Board Statement: Not applicable.

Informed Consent Statement: Not applicable.

Data Availability Statement: The data presented in this study are available on request from the corresponding author. The data are not publicly available due to the possible re-evaluation for future use. 
Acknowledgments: We are grateful to the laboratory staff for their contributions, continued diligence, and dedication to their craft. The authors wish to thank Roland Pieruschka for critically reviewing the manuscript and Ioannis Papadakis for his support. The valuable comments of the editor and three anonymous reviewers are greatly acknowledged.

Conflicts of Interest: The authors declare that they have no known competing financial interests or personal relationships that could have appeared to influence the work reported in this paper.

$\begin{array}{ll}\text { Abbreviations } \\ \text { B } & \text { Boron } \\ \text { BOR } & \text { boric acid/borate transporter } \\ \text { DW } & \text { dry weight } \\ \text { GAE } & \text { gallic acid equivalent } \\ \mathrm{H}_{2} \mathrm{O}_{2} & \text { hydrogen peroxide } \\ \mathrm{LMR} & \text { leaf mass ratio } \\ \mathrm{NIP} & \text { Nodulin 26-like intrinsic protein } \\ \mathrm{RCA} & \text { rubisco activase } \\ \text { RG-II } & \text { rhamnogalacturonan II } \\ \text { ROS } & \text { reactive oxygen species } \\ \text { RUE } & \text { rutin equivalent } \\ \text { SLA } & \text { specific leaf area } \\ \text { TBARS } & \text { Thiobarbituric acid reactive substances } \\ \text { TCA } & \text { trichloroacetic acid } \\ \text { TF } & \text { total flavonoid } \\ \text { TP } & \text { total phenolic }\end{array}$

\section{References}

1. Miwa, K.; Fujiwara, T. Boron transport in plants: Coordinated regulation of transporters. Ann. Bot. 2010, 105, 1103-1108. [CrossRef] [PubMed]

2. Sun, J.; Shi, L.; Zhang, C.; Xu, F. Cloning and characterization of boron transporters in Brassica napus. Mol. Biol. Rep. 2012, 39, 1963-1973. [CrossRef] [PubMed]

3. Voxeur, A.; Fry, S.C. Glycosylinositol phosphorylceramides from Rosa cell cultures are boron-bridged in the plasma membrane and form complexes with rhamnogalacturonan II. Plant J. 2014, 79, 139-149. [CrossRef] [PubMed]

4. Landi, M.; Margaritopoulou, T.; Papadakis, I.E.; Araniti, F. Boron toxicity in higher plants: An update. Planta 2019, $250,1011-1032$. [CrossRef]

5. Papadakis, I.E.; Dimassi, K.N.; Bosabadilis, A.M.; Therios, I.N.; Pataks, A.; Giannakoula, A. Boron toxicity in 'Clementine' mandarin plants grafted on two rootstocks. Plant Sci. 2004, 166, 539-547. [CrossRef]

6. Edelstein, M.; Ben-Hur, M.; Cohen, R.; Burger, Y.; Ravina, I. Boron and salinity effects on grafted and non-grafted melon plants. Plant Soil 2005, 269, 273-284. [CrossRef]

7. Yau, S.K.; Ryan, J. Boron toxicity tolerance in crops: A viable alternative to soil amelioration. Crop Sci. 2008, 48, 853-865. [CrossRef]

8. Kekec, G.; Sakcali, M.S.; Uzonur, I. Assesment of genotoxic effects of boron on wheat (Triticum aestivum L.) and bean (Phaseolus vulgaris L.) by using RAPD analysis. Bull. Environ. Contam. Toxicol. 2010, 84, 759-764. [CrossRef]

9. Cook, B.I.; Mankin, J.S.; Marvel, K.; Williams, A.P.; Smerdon, J.E.; Anchukaitis, K.J. Twenty-first century drought projections in the CMIP6 forcing scenarios. Earth's Future 2020, 8, e2019EF001461. [CrossRef]

10. Gunes, A.; Soylemezoglu, G.; Inal, A.; Bagci, E.G.; Coban, S.; Sahin, O. Antioxidant and stomatal responses of grapevine (Vitis vinifera L.) to boron toxicity. Sci. Hortic. 2006, 110, 279-284. [CrossRef]

11. Pereira, G.L.; Siqueira, J.A.; Batista-Silva, W.; Cardoso, F.B.; Nunes-Nesi, A.; Araújo, W.L. Boron: More than an essential element for land plants? Front. Plant Sci. 2021, 11, 610307. [CrossRef]

12. Chen, Y.; Fanourakis, D.; Tsaniklidis, G.; Aliniaeifard, S.; Yang, Q.; Li, T. Low UVA intensity during cultivation improves the lettuce shelf-life, an effect that is not sustained at higher intensity. Postharvest Biol. Technol. 2021, 172, 111376. [CrossRef]

13. Takano, J.; Noguchi, K.; Yasumori, M.; Kobayashi, M.; Gajdos, Z.; Miwa, K.; Hayashi, H.; Yoneyama, T.; Fujiwara, T. Arabidopsis boron transporter for xylem loading. Nature 2002, 420, 337-340. [CrossRef]

14. Miwa, K.; Takano, J.; Omori, H.; Seki, M.; Shinozaki, K.; Fujiwara, T. Plants tolerant of high boron levels. Science 2007, $318,1417$. [CrossRef]

15. Miwa, K.; Aibara, I.; Fujiwara, T. Arabidopsis thaliana BOR4 is upregulated under high boron conditions and confers tolerance to high boron. Soil Sci. Plant Nutr. 2014, 60, 349-355. [CrossRef] 
16. Tanaka, M.; Wallace, I.S.; Takano, J.; Roberts, D.M.; Fujiwara, T. NIP6;1 is a boric acid channel for preferential transport of boron to growing short tissues in Arabidopsis. Plant Cell 2008, 20, 2860-2875. [CrossRef]

17. Bellaloui, N.; Brown, P.H.; Dandekar, A.M. Manipulation of in vivo sorbitol production alters boron uptake and transport in tobacco. Plant Physiol. 1999, 119, 735-742. [CrossRef]

18. Tsiantas, P.I.; Papadakis, I.E.; Tsaniklidis, G.; Landi, M.; Psychoyou, M. Allocation pattern, nutrient partitioning, sugar metabolism, and pigment composition in hydroponically grown loquat seedlings subjected to increasing boron concentrations. J. Soil Sci. Plant Nutr. 2019, 19, 556-564. [CrossRef]

19. Goldberg, S.; Shouse, P.J.; Lesch, S.M.; Grieve, C.M.; Poss, J.A.; Foster, H.S.; Suarez, D.L. Effect of high boron application on boron content and growth of melons. Plant Soil 2003, 256, 403-411. [CrossRef]

20. Chyla, M.A.; Zyrnicki, W. Determination of metal concentrations in animal hair by the ICP method. Comparison of various washing procedures. Biol. Trace Elem. Res. 2000, 75, 187-194. [CrossRef]

21. Chapman, H.D.; Pratt, P.F. Methods of Analysis for Soils, Plants and Waters; Division of Agricultural Sciences, University of California: Riverside, CA, USA, 1961; p. 309.

22. Hassanvand, F.; Rezaei Nejad, A.; Fanourakis, D. Morphological and physiological components mediating the silicon-induced enhancement of geranium essential oil yield under saline conditions. Ind. Crops Prod. 2019, 134, 19-25. [CrossRef]

23. Lichtenthaler, H.K.; Buschmann, C. Chlorophylls and carotenoids: Measurement and characterization by UV-VIS spectroscopy. Curr. Protoc. Food Anal. Chem. 2001, 1, F4.3.1-F4.3.8. [CrossRef]

24. Kafkaletou, M.; Christopoulos, M.V.; Tsaniklidis, G.; Papadakis, I.; Ioannou, D.; Tzoutzoukou, C.; Tsantili, E. Nutritional value and consumer-perceived quality of fresh goji berries (Lycium barbarum L. and L. chinense L.) from plants cultivated in Southern Europe. Fruits 2018, 73, 5-12. [CrossRef]

25. Singleton, V.L.; Orthofer, R.; Lamuela-Raventos, R.M. Analysis of total phenols and other oxidation substrates and antioxidants by means of Folin-Ciocalteu reagent. Methods Enzymol. 1999, 299, 152-178.

26. Aryal, S.; Baniya, M.K.; Danekhu, K.; Kunwar, P.; Gurung, R.; Koirala, N. Total phenolic content, flavonoid content and antioxidant potential of wild vegetables from Western Nepal. Plants 2019, 8, 96. [CrossRef]

27. Heath, R.L.; Packer, L. Photoperoxidation in isolated chloroplasts. I. Kinetics and stoichiometry of fatty acid peroxidation. Arch Biochem. Biophys. 1968, 125, 189-198. [CrossRef]

28. Papadakis, I.E.; Tsiantas, P.I.; Tsaniklidis, G.; Landi, M.; Psychoyou, M.; Fasseas, C. Changes in sugar metabolism associated to stem bark thickening partially assist young tissues of Eriobotrya japonica seedlings under boron stress. J. Plant Physiol. 2018, 231, 337-345. [CrossRef] [PubMed]

29. Tsaniklidis, G.; Pappi, P.; Tsafouros, A.; Charova, S.N.; Nikoloudakis, N.; Roussos, P.A.; Paschalidis, K.A.; Delis, C. Polyamine Homeostasis in Tomato Biotic/Abiotic Stress Cross-Tolerance. Gene 2020, 727, 144230. [CrossRef]

30. Tsaniklidis, G.; Chatzistathis, T.; Fanourakis, D.; Nikoloudakis, N.; Kotsiras, A.; Delis, C.; Tzortzakakis, E.A. Leaf antioxidant machinery stimulation by Meloidogyne javanica infestation: A case study on Cucumis melo seedlings. Plant Stress 2021, 1, 100002. [CrossRef]

31. Brown, P.H.; Shelp, B.J. Boron mobility in plants. Plant Soil 1997, 193, 85-101. [CrossRef]

32. Francois, L.E. Effect of excess boron on summer and winter squash. Plant Soil 1992, 147, 163-170. [CrossRef]

33. Fanourakis, D.; Aliniaeifard, S.; Sellin, A.; Giday, H.; Körner, O.; Rezaei Nejad, A.; Delis, C.; Bouranis, D.; Koubouris, G.; Kambourakis, E.; et al. Stomatal behavior following mid- or long-term exposure to high relative air humidity: A review. Plant Physiol. Biochem. 2020, 153, 92-105. [CrossRef]

34. Giday, H.; Kjaer, K.H.; Ottosen, C.O.; Fanourakis, D. Cultivar differences in plant transpiration rate at high relative air humidity are not related to genotypic variation in stomatal responsiveness. Acta Hortic. 2015, 1064, 99-106. [CrossRef]

35. Carvalho, D.R.A.; Fanourakis, D.; Correia, M.J.; Monteiro, J.A.; Araújo-Alves, J.P.L.; Vasconcelos, M.W.; Almeida, D.P.F.; Heuvelink, E.; Carvalho, S.M.P. Root-to-shoot ABA signaling does not contribute to genotypic variation in stomatal functioning induced by high relative air humidity. Environ. Exp. Bot. 2016, 123, 13-21. [CrossRef]

36. Lovatt, C.J.; Bates, L.M. Early effects of excess boron on photosynthesis and growth of Cucurbita pepo. J. Exp. Bot. 1984, 35, 297-305. [CrossRef]

37. Seif, M.; Aliniaeifard, S.; Arab, M.; Mehrjerdi, M.Z.; Shomali, A.; Fanourakis, D.; Li, T.; Woltering, E. Monochromatic red light during plant growth decreases the size and improves the functionality of stomata in chrysanthemum. Funct. Plant Biol. 2021, 48, 515-528. [CrossRef]

38. Cervilla, L.M.; Blasco, B.; Ríos, J.J.; Rosales, M.A.; Rubio-Wilhelmi, M.M.; Sánchez-Rodríguez, E.; Romero, R.; Ruiz, J.M. Response of nitrogen metabolism to boron toxicity in tomato plants. Plant Biol. 2009, 5, 671-677. [CrossRef]

39. Perdomo, J.A.; Capó-Bauçà, S.; Carmo-Silva, A.E.; Galmés, J. Rubisco and Rubisco activase play an important role in the biochemical limitations of photosynthesis in rice, wheat, and maize under high temperature and water deficit. Front. Plant Sci. 2017, 8, 490. [CrossRef]

40. Tominaga, J.; Takahashi, S.; Sakamoto, A.; Shimada, H. Arabidopsis BSD2 reveals a novel redox regulation of Rubisco physiology in vivo. Plant Signal. Behav. 2020, 15, 873-876. [CrossRef]

41. Roig-Oliver, M.; Nadal, M.; Clemente-Moreno, M.J.; Bota, J.; Flexas, J. Cell wall components regulate photosynthesis and leaf water relations of Vitis vinifera cv. Grenache acclimated to contrasting environmental conditions. J. Plant Physiol. 2020, $244,153084$. [CrossRef] 
42. Wu, X.; Lu, X.; Riaz, M.; Yan, L.; Jiang, C. Boron deficiency and toxicity altered the subcellular structure and cell wall composition architecture in two citrus rootstocks. Sci. Hort. 2018, 238, 147-154. [CrossRef]

43. Chen, M.; Mishra, S.; Heckathorn, S.A.; Frantz, J.M.; Krause, C. Proteomic analysis of Arabidopsis thaliana leaves in response to acute boron deficiency and toxicity reveals effects on photosynthesis, carbohydrate metabolism, and protein synthesis. J. Plant Physiol. 2014, 171, 235-242. [CrossRef] [PubMed]

44. Aibara, I.; Hirai, T.; Kasai, K.; Takano, J.; Onouchi, H.; Naito, S.; Fujiwara, T.; Miwa, K. Boron-dependent translational suppression of the borate exporter BOR1 contributes to the avoidance of boron toxicity. Plant Physiol. 2018, 177, 759-774. [CrossRef] [PubMed]

45. Du, W.; Pan, Z.Y.; Hussain, S.B.; Han, Z.X.; Peng, S.A.; Liu, Y.Z. Foliar supplied boron can be transported to roots as a boron-sucrose complex via phloem in citrus trees. Front. Plant. Sci. 2020, 11, 250. [CrossRef] [PubMed]

46. Miwa, K.; Tanaka, M.; Kamiya, T.; Fujiwara, T. Molecular mechanisms of boron transport in plants: Involvement of Arabidopsis NIP5;1 and NIP6;1. Adv. Exp. Med. Biol. 2010, 679, 83-96. [PubMed]

47. Mitani-Ueno, N.; Yamaji, N.; Zhao, F.J.; Ma, J.F. The aromatic/arginine selectivity filter of NIP aquaporins plays a critical role in substrate selectivity for silicon, boron, and arsenic. J. Exp. Bot. 2011, 62, 4391-4398. [CrossRef]

48. Macho-Rivero, M.A.; Herrera-Rodríguez, M.B.; Brejcha, R.; Schäffner, A.R.; Tanaka, N.; Fujiwara, T.; Camacho-Cristóbal, J.J. Boron toxicity reduces water transport from root to shoot in Arabidopsis plants. Evidence for a reduced transpiration rate and expression of major PIP aquaporin genes. Plant Cell Physiol. 2018, 59, 836-844. [CrossRef]

49. Tanaka, M.; Takano, J.; Chiba, Y.; Lombardo, F.; Ogasawara, Y.; Onouchi, H.; Naito, S.; Fujiwara, T. Boron-dependent degradation of NIP5;1 mRNA for acclimation to excess boron condition in Arabidopsis. Plant Cell 2011, 23, 3547-3559. [CrossRef]

50. Yoshinari, A.; Takano, J. Insights into the mechanisms underlying boron homeostasis in plants. Front Plant Sci. $2017,8,1951$. [CrossRef]

51. Hrmova, M.; Gilliham, M.; Tyerman, S.D. Plant transporters involved in combating boron toxicity: Beyond 3D structures. Biochem. Soc. Trans. 2020, 48, 1683-1696. [CrossRef]

52. Julkowska, M.M. Adjusting boron transport by two-step tuning of levels of the efflux transporter BOR1. Plant Physiol. 2018, 177, 439-440. [CrossRef]

53. Takano, J.; Tanaka, M.; Toyoda, A.; Miwa, K.; Kasai, K.; Fuji, K.; Onouchi, H.; Naito, S.; Fujiwara, T. Polar localization and degradation of Arabidopsis boron transporters through distinct trafficking pathways. Proc. Natl. Acad. Sci. USA 2010, 107, 5220-5225. [CrossRef]

54. Miwa, K.; Fujiwara, T. Role of overexpressed BOR4, a boron exporter, in tolerance to high level of boron in shoots. Soil Sci. Plant Nutr. 2011, 57, 558-565. [CrossRef]

55. Miwa, K.; Wakuta, S.; Takada, S.; Ide, K.; Takano, J.; Naito, S.; Omori, H.; Matsunaga, T.; Fujiwara, T. Roles of BOR2, a boron exporter, in cross linking of rhamnogalacturonan II and root elongation under boron limitation in Arabidopsis. Plant Physiol. 2013, 163, 1699-1709. [CrossRef]

56. Reid, R.J.; Fitzpatrick, K.L. Redistribution of boron in leaves reduces boron toxicity. Plant Signal. Behav. 2009, 4, 1091-1093. [CrossRef]

57. Dutta, S.; Mitra, M.; Agarwal, P.; Mahapatra, K.; De, S.; Sett, U.; Roy, S. Oxidative and genotoxic damages in plants in response to heavy metal stress and maintenance of genome stability. Plant Signal. Behav. 2018, 13, e1460048. [CrossRef] 